\author{
A.R. Yeshkeyev \\ Ye.A. Buketov Karaganda State University \\ (E-mail: modth1705@mail.ru)
}

\title{
Some properties of Morly rank over Jonsson sets
}

\begin{abstract}
This article introduced and discussed the concepts of minimal Jonsson sets and respectively strongly minimal Jonsson sets. On this basis, it introduces the concept of the independence of special subsets of existentially closed submodel of the semantic model. The notion of independence leads to the concept of basis and then we have an analogue of the Jonsson theorem on uncountable categorical. The concept of strongly minimal, as for sets and so for theories played a decisive role in obtaining results on the description of uncountable - categorical theories. It is well known that Jonsson Theories are a natural subclass of the broad class of theories, as a class of inductive theories. As is known, the basic examples theories of algebra are examples of inductive theories, and they tend to represent an example of incomplete theories. This modern apparatus of Model Theory developed mainly for complete theories, so nowadays technique studying incomplete theories noticeable poorer than for complete theories. Thus, all of the above says that the study of model-theoretic properties Jonsson theories is an actual problem. This article describes the basic properties of the Morley rank over Jonsson subsets of semantic model for some Jonsson theory.
\end{abstract}

Key words: Jonsson theory, Jonsson set, fragment of Jonsson sets, lattice existential formulas of Jonsson theory.

This article is devoted to the study of the concept Jonsson sets and its application. The concept of Jonsson sets defined in [1] and further results were obtained, which were presented in [2-4].

The concept of strongly minimal, as for sets and so for theories played a decisive role in obtaining results on the description of uncountable - categorical theories in [5].

It is well known that Jonsson Theories are a natural subclass of the broad class of theories, as a class of inductive theories. As is known, the basic examples theories of algebra are examples of inductive theories, and they tend to represent an example of incomplete theories. This modern apparatus of Model Theory developed mainly for complete theories, so nowadays technique studying incomplete theories noticeable poorer than for complete theories.

On the one hand Jonsson conditions - a natural algebraic demands that emerge in the study of a broad class of algebras.

On the other hand natural examples Jonsson theories enough, for example, the theory of Boolean algebras, Abelian groups, fields of fixed characteristics, polygons, and so on. These examples are important, as in algebra, and in different areas of mathematics. As can be seen from the following is a list of the scope of the technique developed for studying Jonsson theories can be quite broad.

Thus, all of the above says that the study of model-theoretic properties Jonsson theories is an actual problem.

From the experience of the study of inductive theory [6], it follows that Jonsson theory, as a subclass of inductive theories are such a part in which there are certain methods of investigation incomplete theories, namely the properties of the transfer method of the first order center of Jonsson theories itself Jonsson theories. This method, and on research in the study Jonsson theories and unrelated to the material in this article, we refer the reader to the following sources [7-10].

As noted above, the basic technique associated with more subtle methods of researches of behavior elements of the model, refers to the prerogative of technology study complete theories. Therefore, even just trying to find a generalization of the standard terms of arsenal full of theories, we may come across either a tautology or a concept, which is technically not justified. Therefore, it was proposed and Jonsson set. Recall the basic definitions of [1], which are connected with these sets.

Let there be given an arbitary language $L$.

The theory $\mathrm{T}$ is called Jonsson if it satisfies the following conditions:

1) Theory $T$ has an infinite models;

2) Theory $T$ is inductive;

3) Theory $\mathrm{T}$ admits $J E P$; 
4) Theory T admits $A P$.

Jonsson theory $\mathrm{T}$ is called a perfect theory, if the semantic model is saturated.

Let $T$ - Jonsson perfect theory is full for existential sentences in the language $L$ and its semantic model is . We say that the set $X-\Sigma$-defined, if it is definitely some existential formula.

a) The set $X$ is called Jonsson in the theory $T$ if it satisfies the following properties:

- $X$ is a $-\Sigma$ definability subset of $C$;

- $d c l(X)$ is the universe of some existentially-closed submodels of $C$;

b) The set $X$ is called algebraic Jonsson in the theory $T$, if it satisfies the following properties:

- $X$ is a - definability subset of $C$;

- $\operatorname{acl}(X)$ is the universe of some existentially-closed submodels of $C$.

The definition sets Jonsson can see that they are arranged very simply in the sense of Morley rank [1]. It turns out that the elements of the set-theoretic difference (wells) closing and the set have rank 0; they are algebraic. So, this is a case where we can work with the elements even in the case of incomplete.

The second useful moment of this definition of Jonsson set is that we are closing this set just get some existentially closed model. This in turn gives us firstly to identify Jonsson fragment in the set under consideration and in principle any theory.

At the moment, well enough studied are the perfect Jonsson theories. For them, was proved the criterion of perfectly [7] that allowed to obtain many model-theoretic facts about Jonsson theory and its center. There is a full description of how these theories center and classes of models.

If the case study of complete theories we are mainly dealing with two objects, it herself theory of its models in the case study of Jonsson theory we as models consider the class of existentially closed models of the theory, as well as an additional condition is a certain completeness of this theory in a logical sense.

At least, this theory must be existentially complete.

We give a definition Jonsson fragment. We say that all the $\forall \exists$ - investigation of any theory create Jonsson fragment of this theory, if the deductive closure of these $\forall \exists$ - consequences are Jonsson theories.

Due to the fact that this is not always true, it would be interesting to be able to allocate in an arbitrary theory a part that will Jonsson theory. This problem takes place if only because of the fact that any theory morlization us it provides, moreover, the resulting theory is perfect [6].

Another way is the use of the fact that any countable model of inductive theory necessarily isomorphic to invest in some existentially closed model of the theory [6]. Then we consider all $\forall \exists$ - sentences true in this model.

Then in the case Jonsson theory is well known fact that $\forall \exists$ - sentences are true in the existentially closed model form the Jonsson theories. Otherwise, at the moment apart from enriching the signature (in case skolemization morlezation and [6]), we have no way to reach Jonsson theory.

To study the behavior of elements in case wells Jonsson sets, we can always see $\forall \exists$ - sentences is true in the above closures Jonsson set. In By the above, in this case, that consideration of the set of suggestions will Jonsson theory.

Obtained in this case will be called a theory Jonsson fragment corresponding Jonsson set. It is clear that we can carry out research Jonsson fragments about the connection to the original theory that the new formulation of the problem is the study of Jonsson's theory.

The main objective of this article is the following problem:

Recall that Jonsson theory $\mathrm{T}$ has a semantic model of high power enough. If this model is saturated, this Jonsson theory is called perfect. Semantic models of perfect Jonsson theory uniquely determined by their power.

Furthermore, since we are dealing with a perfect Jonsson theories, it is convenient for us to work within a large semantic existentially closed model containing all other existentially closed model considered perfect Jonsson theory. We call this model of universal existential area.

It can also be characterized by the following conditions.

1. Each model of this theory is isomorphic to put in $\mathfrak{C}$.

2. Every isomorphism between the two submodels extends to an automorphism of model $\mathfrak{C}$.

We will not consider all the subsets, and only a subset of the Jonsson.

For any $\Sigma$ - definable subsets of semantic model we have, the following result.

Lemma 1. $\Sigma$-definable subset of the semantic model is definable over a set of parameters $A$ semantic model if and only if it is invariant under all automorphisms of the model $\mathfrak{C}$, leaving in place each element of $A$.

It follows that the definable closure $\operatorname{dcl}(A)$ of Jonsson sets $A$, i.e, the set of all elements, definable over $A$, coincide with the set elements that are invariant relatively all automorphisms over $A$. 
From Lemma 1 it follows that the element $b$ is algebraic over $A$ if and only if it has only a finite number of conjugates over $A$.

We define the rank of Morley for existentially definable subsets of the semantic model.

We want to assign to each $\Sigma$ - is definable subset $D$ of the semantic model ordinal number (or, perhaps, -1 or $\infty$ ) - its rank Morley, denoted by $M R$.

First, we define relation $M R(\mathbb{D}) \geq \alpha$ by recursion on the ordinal $\alpha$.

Let $T$ is perfect Jonsson theory, $C$-its semantic model. $D$ is a definable subset of $C$.

Definition 1:

$-M R(\mathbb{D}) \geq 0$ if and only if $\mathbb{D}$ is empty;

$-M R(\mathbb{D}) \geq \lambda$ if and only if $M R(\mathbb{D}) \geq \alpha$ for all $\alpha<\lambda(\lambda$ - the limiting ordinal);

$-M R(\mathbb{D}) \geq \lambda$ if and only if $\mathbb{D}$ exists an infinite family $\left(\mathbb{D}_{i}\right)$ disjoint $\Sigma$ definable subsets, such that

$$
M R\left[(\mathbb{D})_{i}\right] \geq \lambda \text { for all } i
$$

Then Morley rank of class $\mathbb{D}$ is $M R(\mathbb{D})=\sup \{\alpha \mid M R(\mathbb{D}) \geq \alpha\}$.

Moreover, we assume that $M R(\emptyset)=-1$ and $M R(\mathbb{D})=\infty$ if $48 /$ for all $\alpha$ (in the latter case we say that $\mathbb{D}$ has not rank).

Note that $\Sigma$ - definable class has rank -1 if it is empty; rank 0 if it is finite; rank 1 if it is infinite, but does not contain an infinite family of disjoint infinite $\Sigma$ - definable classes.

Lemma 2. The relation $M R\left(\mathbb{D}_{1} \cup \mathbb{D}_{2}\right)=\max \left(M R\left(\mathbb{D}_{1}\right), M R\left(\mathbb{D}_{2}\right)\right.$ is true.

Definition 2. The degree of Morley $M d(\mathbb{D})$ Jonsson subset $\mathbb{D}$ of semantic nodel having Morley rank $\alpha$ is the maximum length $d$ of its decomposition $\mathbb{D}=\mathbb{D}_{1} \cup \ldots \cup \mathbb{D}_{d}$ into disjoint existentially definable subsets of rank $\alpha$.

In the case of rank 0 degree existentially definable subset $\mathbb{D}$ is a simply a number of its elements. If existentially definable subset has not rank, it is not determined the degree of Morley.

Consider Jonsson minimal sets. Then under the structure of the model refers to the signature of model or of the language $L$ under consideration Jonsson theory.

Let $\mathcal{M}$ is the structure, and let $\mathbb{D} \subseteq M^{n}$ the infinite $\Sigma$ - defining subset. We say that $D$ is minimal in $\mathcal{M}$ if any for the $\Sigma$ - defining $Y \subseteq \mathbb{D}$ either $Y$ is finite or $\mathbb{D} / Y$ is finite. If $\phi(\bar{v}, \bar{a})$ is a formula that determines the $\mathbb{D}$, then we can also say that $\phi(\bar{v}, \bar{a})$ is minimal. $\mathcal{M}$.

We say that $\mathbb{D}$ and $\phi$ are Jonsson strongly minimal, if $\phi$ is minimal any existentially closed extensions $\mathcal{N}$ of

We say that theory $\mathrm{T}$ is Jonsson strongly minimal if $\forall \mathcal{M} \in E_{T}, \mathcal{M}$ is Jonsson strongly minimal. Consider the example of the algebraic closure of a few Jonsson strongly minimal theories.

If $K$ is an algebraically closed field and $A \subseteq K$, then $\operatorname{acl}(A)$ is algebraically closed subfield generated.

The following properties of the algebraic closure true for any algebraically Jonsson set $\mathbb{D}$

If $A \subseteq B$, then $\operatorname{acl}(A) \subseteq \operatorname{acl}(B)$.

If $a \in \operatorname{acl}(A)$ then $a \in \operatorname{acl}\left(A_{0}\right)$ for some finite $A_{0} \subseteq A$.

A more subtle property is true if $\mathbb{D}$ is Jonsson strongly minimal.

Lemma about a replacement. Suppose that $\mathbb{D}$ is a subset of the semantic model of the theory and it Jonsson strongly minimal $A \subseteq \mathbb{D}$ and $a, b \in \mathbb{D}$. If $a \in \operatorname{acl}(A \cup\{b\}) \backslash \operatorname{acl}(A)$, then $b \in \operatorname{acl}(A \cup\{a\})$.

Remark. Jonsson strongly minimal set is existentially definable subset of the semantic model of the theory of rank 1 and degree 1 in the sense of Morley.

Definition 3:

1. Jonsson Theories $T$ is Jonsson totally transcendence, if every existentially definable subset of its semantic model has Morley rank.

2. Theory $T$ is Jonsson $\omega$-stable if the number of existential types is countable for every countable subset A of semantic model.

Theorem. Jonsson theory $T$ is Jonsson totally transcendence, if and only if it is Jonsson $\omega$ - stably.

Lemma 3. Let $a$ and $b$ are an arbitary elements of the semantic model. If the element $b$ algebraically over $A$ and $a$, where $A$ is existentially definable subset of the semantic model, then $M R(b / A) \leq M R(a / A)$.

Corollary 1. Let $M$ - some $\omega$-saturated existentially closed submodel semantic model, $\varphi$ some $L(M)-$ formula rank $\alpha$ and degree $d$ in Morley. Then we can expand $\varphi$ on $L(M)$ - formulae $\varphi_{1}, \ldots, \varphi_{m}$ of rank $\alpha$ and degree 1.

Anyway Jonsson strongly minimal set, we can define the concept of independence, which generalizes linear independence in vector spaces and algebraic independence of algebraically closed fields. 
We fix $\mathcal{M}$ and $D$ is Jonsson strongly minimal set in $\mathcal{M}$ existentally closed under the model semantic model of Jonsson theory $T$.

Definition 4. We say that $A \subseteq D$ independently if $\alpha \notin \operatorname{acl}(A\{a\})$ for all $a \in A$. If $C \subset D$ we say that $A$ independently over $C$, if $\alpha \notin \operatorname{acl}(C \cup A\{a\})$ for all $a \in A$.

We show that the endless independent sets are sets of indistinguishable elements.

Lemma 4. Suppose $T$ is Jonsson strongly minimal theory and $\phi(v)$ is Jonsson strongly minimal formula with parameters from $A$, where either $A \neq \emptyset$ or $A \subseteq M_{0}$ where $\mathcal{M}_{0} \models E_{T}, \mathcal{M}_{0} \prec_{1} \mathcal{M}$ and $\mathcal{M}_{0} \prec_{1} \mathcal{N}$. If $a_{1}, \ldots, a_{n} \in \phi(M)$ independent over $A$ and $b_{1}, \ldots, b_{n} \in \phi(N)$ are independent over $A$, then complete existential types $t p^{\mathcal{M}}(\bar{a} / A), t p^{\mathcal{N}}(\bar{b} / A)$ are equal.

Corollary 2. If $\mathcal{M}, \mathcal{N} \models T$, and $\phi(v)$ as indicated above, $B$ is an infinite subset $\phi(\mathcal{M})$ independent over $A$ and $C$ is an infinite subset $\phi(\mathcal{N})$ independent over $A$, then $B$ and $C$ are indistinguishable infinite sets of the same type over $A$.

Therefore, power is the only way to distinguish independent subset $\mathbb{D}$.

Definition 5. We say that $A$ is the basis for $Y \subseteq \mathbb{D}$ if $A \subseteq Y$ independent and when $\operatorname{acl}(A)=\operatorname{acl}(Y)$.

It is obvious that any maximal independent subset of $Y$ is a basis for $Y$. Just as in the vector spaces and algebraically closed fields, any two bases have the same capacity.

\section{References}

1 Ешкеев А.Р. Йонсоновские множества и их некоторые теоретико-модельные свойства // Вестн. Караганд. ун-та. Сер. Математика. - 2014. - № 2(74). - C. 53-62.

2 Yeshkeyev A.R. The similarity of Jonsson sets. Abstracts. V congress of the Turkic World Mathematicians. Kyrgyzstan, Issyk-Kul, June, 5-7. - 2014. - P. 217.

3 Yeshkeyev A.R. Jonsson sets and some of their model-theoretic properties: Abstracts Book. International Congress of Mathematicians, August, 13-21, 2014, Seoul, Korea. - P. 8.

4 Yeshkeyev A.R. On Jonsson sets and some their properties // Bull. of Symbolic Logic. — 2015. - Vol. 21. - No. 1. - P. 99-100.

5 Baldwin John T., Lachlan Alistair H. On Strongly Minimal Sets. The Journal of Symbolic Logic // Journal of Symbolic Logic. - 1971. - Vol. 36. - No. 36(1). - P. 79-96.

6 Справочная книга по математической логике: В 4 ч. - Ч.1. Теория моделей / Под ред. Дж. Барвайса; пер. с англ. - М.: Наука; Гл. ред. физ.-мат. лит., 1982. - С. 126.

7 Ешкеев А.Р., Касыметова М.Т. Йонсоновские теории и их классы моделей. - Караганда: Изд-во КарГУ, 2016. - C. 346.

8 Yeshkeyev A.R. Properties of central type for fragments of Jonsson sets // Bull. of Symbolic Logic. 2016. - Vol. 22. - No. 3. - P. 429, 430.

9 Yeshkeyev A.R. The Properties of Positive Jonsson's Theories and Their Models // International Journal of Mathematics and Computation. - 2014. - Vol. 22.1. - P. 161-171.

10 Yeshkeyev A.R. On Jonsson stability and some of its generalizations // Journal of Mathematical Sciences. - Springer, New-York, 2010. - Vol. 166. - No. 5. - P. 646-654. 


\title{
А.Р. Ешкеев \\ Йонсондық жиындардың ішіндегі Морли рангінің кейбір қасиеттері
}

\begin{abstract}
Мақалада йонсондық жиындар ұғымы енгізілген және қарастырылған. Осы негізде семантикалық модельдің экзистенционалды тұйық ішкі моделінің тәуелсіз арнайы ішкі жиындары ұғымы енгізілді. Тәуелсіздік ұғымы базис ұғымына алып келеді және әрі қарай біз саналымсыз үзілді-кесілгендігі туралы теореманың йонсондық аналогін қарастырдық. Қатты минималды ұғымы саналымсыз-үзілдікесілгендігі теориялардың сипаттауының нәтижесін алу үшін теориялар сияқты жиындар үшін де үлкен рөл атқарады. Йонсондық теориялар индуктивті теориялар класы сияқты теорияның кең класы болатын кәдімгі ішкі класты көрсететіні белгілі. Бізге алгебра теориясының негізгі мысалдары белгілі. Олар индуктивті теориялардың мысалдары да бола алады және ереже бойынша олар толық емес теориялардың мысалдары. Сонымен қатар модельдер теориясының қазіргі зерттеу аппараты толық теориялар үшін дамыған, сондықтан бүгінгі таңда толық теорияларға қарағанда, толық емес теорияларды зерттеу техникасы анағұрлым кем дамыған. Яғни, жоғары айтқандардан йонсондық теорияның модельді-теоретикалық қасиеттерін оқу өзекті мәселе болып табылады. Мақалада кейбір йонсондық теориялар үшін йонсондық ішкі жиындардың семантикалық модельдері мен Морли рангінің негізгі қасиеттері сипатталды.
\end{abstract}

\section{A.P. Ешкеев}

\section{Некоторые свойства ранга Морли над йонсоновскими множествами}

В статье введены и рассмотрены понятия «йонсоновские множества» и, сответственно «сильно минимальные йонсоновские множества». На этой основе введено понятие независимости специальных подмножеств экзистенциально замкнутой подмодели семантической модели. Понятие независимости приводит к понятию базиса, и далее мы имеем йонсоновский аналог теоремы о несчетной категоричности. Понятие сильной минимальности, как для множеств, так и для теорий, сыграло решающую роль при получении результата об описании несчетно-категоричных теорий. Хорошо известно, что йонсоновские теории представляют собой естественный подкласс такого широкого класса теорий, как класс индуктивных теорий. Как известно, основные примеры теорий алгебр являются примерами индуктивных теорий, и они, как правило, представляют пример неполных теорий. При этом современный аппарат теории моделей развивался в основном для полных теорий, поэтому на сегодняшний день техника изучения неполных теорий заметно беднее, чем для полных теорий. Таким образом, всё сказанное выше говорит о том, что изучение теоретико-модельных свойств йонсоновских теорий является актуальной задачей. Эта статья описывает основные свойства ранга Морли над йонсоновскими подмножествами семантической модели для некоторых йонсоновских теорий.

\section{References}

1 Yeshkeyev A.R. Bull. of Karaganda University, Ser. Mathematics, 2014, 2(74), p. 53-62.

2 Yeshkeyev A.R. The similarity of Jonsson sets: abstracts. V congress of the Turkic World Mathematicians, Kyrgyzstan, Issyk-Kul, June, 5-7, 2014, p. 217.

3 Yeshkeyev A.R. Jonsson sets and some of their model-theoretic properties. Abstracts Book. Inter-national Congress of Mathematicians, August, 13-21, 2014, Seoul, Korea, p. 8.

4 Yeshkeyev A.R. Bull. Symbolic Logic, 2015, 21, 1, p. 99, 100.

5 Baldwin John T., Lachlan Alistair H. Journal of Symbolic Logic, 1971, 36, 36(1), p. 79-96.

6 Handbook of mathematical logic: In 4 parts / Ed. it Dzh. Barvaysa, Ch.1. Teoriya models: Per. from English, Moscow: Nauka; Home Editorial physical and mat. literature, 1982, p. 126. 
7 Yeshkeev A.R., Kasymetova M.T. Jonsson theory and its classes of models, Karaganda: KSU Publ., 2016, p. 346.

8 Yeshkeyev A.R. Bull. Symbolic Logic, 2016, 22, 3, p. 429, 430.

9 Yeshkeyev A.R. International Journal of Mathematics and Computation, 2014, 22.1, p. 161-171.

10 Yeshkeyev A.R. Journal of Mathematical Sciences, Springer, New-York, 2010, 166, 5, p. 646-654. 